\title{
The Politics of Local Regulation in Tanzania: The Quest for Multilevel Regulatory Governance
}

\author{
Beatrice Mkunde \\ The Mwalimu Nyerere Memorial Academy, Dar es Salaam, Tanzania
}

\begin{abstract}
Regulation is currently perceived as an art and craft of governance where the regulatory processes are an outcome of interdependences between political actors, bureaucrats, business community, and the public at large. However, it is now extensively recognized that this interdependency is beyond one level of government particularly in the era of decentralization where regulatory outcomes are a result of a complex set of interacting levels. This study concedes that regulatory processes are intrinsically political endeavor. Principally, local government regulatory processes are characterized by multiple actors at different levels of governance, i.e., the local government itself and stakeholders within its jurisdiction and the central government. In fact power dispersion has a vertical direction consisting of actors stemming from different governmental levels as a consequence of decentralization. The complexities of the relationships of multiple actors at different levels of government and across the same level of government create a number of risks that jeopardize quality local regulation that need to be managed calling for multilevel regulatory governance anchored on effective stakeholder engagement and coordination. Particularly, engagement with local government during the design of new regulations is largely poor resulting in a missed opportunity to have informed decisions that enhance quality local regulation. To augment multilevel governance, it is imperative to improve the interface between central and local government with local authorities recognized as "co-producers" of regulatory outcomes. Effective implementation of Regulatory Impact Assessment (RIA) that safeguards proper analysis of proposed and existing regulation is of paramount importance to ensure evidenced based regulations, analysis of cost implications for the local government, the capacity of LGAs in to implement as well as legitimacy of regulations. Therefore this study examines the political tradeoffs between the central and local government and among other stakeholders.
\end{abstract}

Keywords: regulation, local regulation, multilevel regulatory governance

For this study, regulation is defined to comprise both legal and informal instruments through which central government, local government, and the community seeks to manage the behavior of citizens and business in order to achieve socio-economic and environmental outcomes. Regulation includes primary legislation, subordinated legislation (delegated law making, including the bylaws and planning instruments for which local government has responsibility), licenses, codes and consents, rules, informal instruments and agreements. Regulation is perceived as an art and craft of governance where the regulatory processes are an outcome of interdependences between political actors, bureaucrats, business community, and the public at large

Beatrice Mkunde, lecturer and Ph.D. candidate at the University of Dar es Salaam, Department of Social Studies, The Mwalimu Nyerere Memorial Academy, Dar es Salaam, Tanzania. 
(Gourevitch, 1978; Tsebelis, 1990). Regulation is formulated to achieve specific objectives and is thus one form of governance.

It is well established that there is interdependency in the regulatory process that goes beyond one level of government particularly in the era of decentralization where regulatory outcomes are a result of a complex set of interacting levels (Aubin \& Verhoest, 2014; Black, 2008; Coen \& Héritier, 2005; Jordana \& Sancho, 2004). As a mode of governance, regulations ought to be of good quality, i.e., be proportionate; accountable; consistent; transparent; and targeted (UK's Better Regulation Taskforce, 2003) to create a predictable regulatory environment and ensure responsive consultation. Indeed, the overarching objective of regulatory policy is to ensure that regulation works effectively, and is in the public interest (OECD, 2011). However, if regulation is used when it is not needed, or is poorly designed and executed, it can fail to achieve policy objectives and have negative consequences that harm the wellbeing of citizens of Tanzania particularly at the local level.

Of particular significance in this study is the fact that regulatory processes are inherently political endeavor. Principally, local government regulatory processes are characterized by multiple actors at different levels of governance, i.e., the local government itself and stakeholders within its jurisdiction and the central government. In fact, power dispersion has a vertical direction, consisting in the involvement of actors stemming from different governmental levels, as a consequence of decentralization (Hooghe \& Marks, 2003). The regulation of a given field most generally involves various governmental levels as well as various types of actors on a single governmental level (Aubin \& Verhoest, 2014). Such arrangements of multilevel regulatory arrangements involving multiple regulatory actors may run into a series of problems such as rule duplication, overlapping and low quality regulations, uneven enforcements or complex administrative demands with negative impact on economic activity (Rodrigo et al., 2009).

Due to the complexities of the relationships, multiple actors at different levels of government, and across the same level of government create a number of risks for good regulatory governance and effective regulation that need to be managed to safeguard quality regulation at the local level. Firstly, there is information gap characterized by information asymmetries between levels of government when designing, implementing regulations as local governments are likely to have more information about local needs, preferences, and implementation costs. Secondly, capacity gap is created when there is a lack of human, knowledge (skill-based), or infrastructural resources available to implement and from central government. Thirdly, an accountability gap may occur where there are unclear or overlapping responsibilities across and between levels of government for regulatory decisions. The absence of clear accountabilities has direct implications for incentives on actors within the regulatory system and incentives for performance (OECD, 2009). There is also a tendency that central government agencies do not take full account of the impact of new regulations on local government by adequately consulting with local government prior to introducing new regulations. Central government agencies too quickly decentralize enforcement responsibilities to local authorities without understanding the financial and capability constrain that may limit their ability to undertake enforcement.

These relationship complexities call for the growing importance of multilevel regulatory governance founded on the interaction between the interplay of regulatory actors to influence regulatory outcomes. The interaction is both vertical and horizontal, with the former describing interactions between actors from local government and the latter with between the central and local government. Particularly, multilevel regulatory governance put emphasis on effective engagement of both vertical and horizontal partners and co-ordination in 
the regulatory processes. This paper examines the political tradeoffs between the central, local government and among other stakeholders within the jurisdiction of local government such as the business community and the citizens bearing in mind that regulatory outputs depend on power of influence. The study assumes that for quality regulations that facilitate multilevel governance, Tanzanian regulatory regime needs effective engagement and co-ordination between the two levels of government and effective participation of local stakeholders. Questions in this study revolve around who shapes local regulations and whether there are governance issues which impede the efficiency of local government regulation outcomes. The data used for the study is based on the analysis of the legislations that prescribes procedures for making regulatory decisions at the local level and some interviews from legal officers in the local government authorities.

\section{Regulatory Processes at the Local Government: The Legal Framework}

The laws that are made by persons or authorities under the provisions of Article 97(5) of the URT constitution are often referred to as subsidiary (delegated) legislation. Subsidiary (delegated) legislation could take the form of regulations, rules, or by-laws. Other than from the Constitution, other main legislations that govern the by-law making process by local government authorities (Cities and District Councils, townships, municipalities, and villages) generally are the following: The Interpretation of Laws Act, Cap. 1 R.E. 2002; The Local Government (District Authorities) Act, Cap. 287, R.E. 2002; and The Local Government (Urban Authorities) Act, Cap. 288 R.E. 2002. As conceived by Alexis de Tocqueville and John Stuart Mill (2011), local governments are machineries that facilitate and articulate the local "voice". By-laws serve as a useful tool in realizing the decentralization process particularly, empowering local communities to determine the manner in which the resources in their areas should be utilized. Indeed, local government is primarily a form of representative democracy.

Section 150 of the Local Government (District Authority) Act stipulates that before by-laws are submitted to the respective minister for consent the local government authority should give a notice to all inhabitants within the local government calling upon all the interested and affected parties to lodge their objection in writing. The Local Government (Urban Authorities) provides duration of two weeks' notice. Additionally, publication of draft village by-laws is to be effected in an open place that people usually frequent before they come into operation. This could be at the market place, local government (village leader's) offices and places of worship. Village by-laws come into operation after being approved by the District Council.

\section{Ministerial Level Regulatory Processes}

The respective minister for local government authorities is empowered by both the Local Government Authorities (local and urban) to make regulations to be administered by the local government. For instance, Section 112(1-3) of the Local Government (District Authorities) Act stipulates that:

For the purpose of ensuring the better performance by local government authorities of their general functions in accordance with the objects, purposes and provisions of this Act the responsible minister makes regulations more particularly specifying the powers and duties to be exercised by any local government authority, or by any category of local government authorities, or by all local government authorities.

Sub-section (3) emphasizes that:

It shall be the duty of every local government authority in relation to which regulations are made under this section, to exercise the powers and discharge the duties conferred or imposed by the regulations to the best of its ability and resources. 
However, Section 113 states that where a minister other than the respective minister makes regulations to be administered by the local government, consultation has to be sought from the respective minister. For instance, the minister responsible for natural resources may make regulations for the management of forest resources. He may also make model forest management by-laws for local government authorities to consider for adoption. Section 147 confers powers to the respective minister to make uniform by-laws where in his opinion such by-laws are necessary or desirable, for the purposes of the better development and fostering of the system of local government. With regards to governance procedure particularly participation, the Act requires publications of the by-laws before their operation. The act requires the minister to give a two months' notice in the gazette or any other newspaper accessible to the intended locality indicating the purpose of the by-law. The particular local authority and affected persons may lodge objections in writing to the minister.

\section{Findings: Multilevel Governance Issues}

A multilevel perspective enhancing governance requires clear responsibilities, engagement, coordination, and accountability at both levels as high-quality regulation in one level of government can be undermined by poor regulatory policies and practices at other levels. Regulatory processes at the local level should be responsive to governance principles (Ruffing, 2015). This can be safeguarded by involving elected councilors, general involvement of local government in regulatory process that are to be enforced by the local government and public participation that engages all affected stakeholders. The intention of publicizing these is to provide an opportunity for people to air their views on the by-laws, avoid conflicts, and facilitate a smooth implementation and enforcement mechanism (OECD, 2013).

Interviews with the legal officers at the local government indicate that regulations that are made by the local government largely adhere to governance principals particularly stakeholder engagement. One legal officer from Hai District stated that:

The legal draft is taken to stakeholders from the levels of village and ward including other government and private institutions who are given a period of not less than 30 days to give their views. The Council Management Team then discusses the draft to amend views before proceeding to full council meeting. The draft with attached lower level minutes is submitted to the Regional Commissioner for presentation to the respective minister. The minister submits the daft to the Attorney General for certification before submitting to government printers for editing and finally to government Gazette.

These findings suggest that local government largely upholds to the principal of governance. Particularly, it can be observed that stakeholders are given ample time to air their views. Nonetheless, neither the Act nor are there guidelines that give councils guidance as to the most effective way to consult their communities on the content of a proposed local regulation. The lack of guideline on consultation provides room for stronger groups or politicians to sway regulatory decisions to their advantage. The guidelines would assist in assessing the potential costs to council in implementing and enforcing the proposed regulation and better ways of consultation. Effective consultation provides the potential impact on affected groups, particularly small business, in meeting the requirements of the proposed local regulation; how affected groups will be informed of the impact of the regulation including any planned education and publicity campaigns. Similarly, the question of feedback is not given importance. Once stakeholders give their views that there is no feedback informing them whether or not their views were taken into account. The lack of feedback may discourage stakeholders from airing their views.

At the same time, one would expect that since councilors are citizens' representatives they would ensure 
that regulations are citizen centered. This is based on the assumption that elected members of the local government make decisions while local bureaucrats implement those decisions. Nonetheless, some regulatory outcomes at the local government are largely ineffective due to marginal representation of the councilors. It was found by Kessy (1999) in his research of two district councils (Moshi and Lushoto) that, most of the decision making process from agenda setting to the implementation stage, is mainly controlled by local bureaucrats. This phenomenon, according to the study, is attributed to the central government's reluctance in emphasizing high quality councillorship. Instead, the outdated provision of someone who can read and write is the criteria used to elect councilors. The level of interaction between councilors and council officers in the decision making process is minimal. It is legitimate for councils to respond to community needs and to achieve key strategic policy objectives through the use of local laws.

Thus, poorly considered or poorly designed regulation by the local government can place undue burdens on business and the community and impede business growth and development. It can also increase the enforcement costs to council and produce unintended side-effects. In the worst case the costs and risks of regulation can outweigh the benefits.

With regards to regulations from the central government, findings show that some of these regulations are not effectively implemented. This is due lack of proper analysis of the proposed regulation to determine the capacity of local authorities to implement. For instance one legal officer notes that:

Some of these regulations cannot be implemented. There is a regulation from the ministry of Agriculture and livestock development which we felt we could not implement. The ministry did not do proper analysis to determine contextual differences among districts. As such we had to reject the regulation by filing our complaints to the Attorney General for further actions.

Besides, local governments are either not consulted or given very few days to give their inputs. One legal officer lamented:

There are occasions that there are intentional technical delays and we are only given three day to read and give our comments... with those few days there is apparently nothing to be done.

The level and quality of engagement with the local government in the design of new regulations is generally poor and, as such, is undermining the quality of local regulation. The inadequacy of engagement with local government by central government was a recurring theme emerging from this study suggesting that some of these regulations are politically influenced at the ministerial level. They claimed that central government imposes regulatory responsibilities and obligations on councils without fully considering their impacts and costs. Considerations include whether or not implementation requirements are likely to vary from region to region. As reveled from legal officers from the local governments there is often limited analysis of local government's capability or capacity to implement regulations prior to the allocation of additional regulatory functions (or changes to existing functions). Respondents emphasized the benefits for involving local governments early in the policy development process and providing guidance on how meaningful engagement can be achieved. Effective engagement would consequently reduce information asymmetry between the local and central government to enhance informed decision making.

Nonetheless, as one legal officer noted, there seem to be some hope for early engagement in future regulatory processes by the central government. He claims that at least for the first time years legal officers in all councils have been invited by the respective ministers regarding regulatory processes. 


\section{Conclusions and Way Forward}

It can be concluded that complexities of the relationships of multiple actors at different levels of government and across the same level of government create a number of risks that jeopardize quality local regulation. As seen in the findings, local governments produce their own regulations as enshrined in the local government Act. In respect to governance at the level of local government, the principle of participation by stakeholders is adhered to albeit challenges. One of these challenges is the lack of guidelines on how well to engage stakeholders. Another is inadequate qualitative and quantitative analysis of regulations to determine their positive and negative impacts to affected groups.

Indeed, local government regulation is mostly shaped by central government empowered by legislations. However, there are challenging governance issues that constrain quality regulations and effective implementation. Findings indicate that there is poor engagement of the local level in the designing of regulations. Particularly, poor analysis of the capacity of local government to implement these regulations constrains effective implementation and thereby inhibits the overall achievement of local policy goals.

To improve multilevel regulatory governance the study suggests the interface between central and local government to be improved with local authorities recognized as "co-producers" of regulatory outcomes. Meaningful engagement and effective dialogue with local government needs to occur early in the policy process. The regulatory processes should follow Regulatory Impact assessment (RIA) framework that is vital in providing informed decision-making. RIA assists in problem definition through to option selection, identification, and assessment of likely impacts, implementation and ongoing monitoring and review of the existing regulation. Such assessment and engagement are an important reality check on regulatory proposals ensuring that regulatory outcomes are achieved at least cost and minimum impact to affected groups. There is also a need to establish institutional mechanisms for multilevel co-ordination and dialogue.

\section{References}

Aubin, D., \& Verhoest, K. (Eds.). (2014). Multi-level regulation in the telecommunications sector. Basingstoke: Palgrave Macmillan. The New Zealand Productivity Commission (2012) Local Government Regulatory Performance.

Baldwin, R. (2010). Better regulation: The search and the struggle. In R. Baldwin, M. Cave, and M. Lodge (Eds.), The Oxford handbook of regulation (Ch. 12). Oxford: Oxford University Press.

Black, J. (2008). Constructing and contesting legitimacy and accountability in polycentric regulatory regimes. Regulation \& Governance, 2(2), 137-164.

Coen, D., \& Héritier, A. (Eds.). (2005). Refining regulatory regimes: Utilities in Europe. Cheltenham: Edward Elgar.

Gourevitch, P. (1978). The second image reversed: The international sources of domestic politics. International Organization, 32, 881-911.

Hooghe, L. G., \& Marks, G. (2003). Unravelling the central state, but how? Types of multi-level governance. American Political Science Review, 9(2), 233-243.

Jordana, J. S., \& Sancho, D. (2004). Regulatory designs, institutional constellations and the study of the regulatory state. In J. Jordana and D. Levi-Faur (Eds.), The politics of regulation: Institutions and regulatory reforms for the age of governance (pp. 296-319). Cheltenham: Edwar Elgar.

Kessy, A. T. (1999). The dynamics of decision making in local government in Tanzania. The case of Moshi and Lushoto District-Councils (MA Thesis).

Local Government (District Authorities) Act No. 7 of 1982. (1982). Retrieved from https://www.policyforum-tz.org/sites/default/files/LocalGovtDistrictAuthoritiesAct71982.pdf

Local Government (Urban Authorities) Act No. 8 of 1982. (1982). Retrieved from http://tanzania.eregulations.org/media/The_local_government_urban_authorities_act_8-1982.pdf

OECD. (2004, April 2). Multi-level regulatory governance. Paris: OECD publishing. 
OECD. (2009). Improving the Quality of Regulations\|, Policy Brief, November. Paris: OECD publishing.

OECD. (2011). Regulatory policy and governance: Supporting economic growth and serving the public interest. Paris: OECD publishing.

OECD. (2013). Principles for the governance of regulators. Paris: OECD Publishing.

Rodrigo, D., Allio, L., \& Andres-Amo, P. (2009). Multilevel Regulatory Governance: Politics, Institutions and tools for regulatory quality and policy coherence. Paris: OECD Publishing.

Ruffing, E. (2015). Agencies between two worlds: Information asymmetry in multilevel policy-making. Journal of European Public Policy, 22(8), 1109-1126.

Tsebelis, G. (1990). Nested games: Rational choice in comparative politics. California: University of California Press.

UK's Better Regulation Task Force. (2003). Principles of Good Regulation. 